\title{
Russisk pres på Strasbourg
} Henrik Døcker

\author{
Rusland har stukket en kæp i hjulet for en effekti- \\ visering af den europæiske menneskerettigheds- \\ konventions anvendelse. Samtidig reagerer det \\ voldsomt mod afgørelser vedrørende Tjetjenien \\ og Transdnestr. Retsbeskyttelsen af russiske borge- \\ re er desuden usikker
}

At overholde menneskerettighederne kræver ikke alene den øverste regeringsmagts vilje, men også forvaltningens og domstolenes evne hertil. Når Rusland således siden 1998 har været bundet af den europæiske menneskerettighedskonvention, betyder det desuden en forpligtelse til at respektere afgørelser fra Den Europæiske Menneskerettighedsdomstol, som griber ind i Ruslands forhold til fremmede magter, med andre ord landets officielle udenrigspolitik. Den læreproces alt dette kræver, tager lang tid, ikke mindst for staterne i Østeuropa.

Præsident Vladimir Putin affyrede en egentlig bredside mod Menneskerettighedsdomstolen, da han kort efter nytår 2007 talte til et møde i Kreml, hvor repræsentanter for Europarådet i Strasbourg og en række ngo'er (ikke-statslige organisationer) var til stede. "Desværre stilles vores land over for en politisering af Menneskerettighedsdomstolen" hed det med særlig henvisning til en dom om Ruslands ansvar for hvad der foregår i den østlige del af republikken Moldova, der er 'sprængt fra' i det reelt selvstyrende område Transdnestr, der dog de jure stadig er en del af Moldova (se nedenfor).

Et kig på Menneskerettighedsdomstolens statistik over afsagte domme i 2006 er ikke umiddelbart særlig skræmmende for så vidt angår Rusland: Der blev afsagt 102 domme med krænkelse i 96 af dem, Tyrkiet var således oppe på 334 domme, ud af de godt 1500 , der sammenlagt blev afsagt blandt de i alt 46 medlemslande af Europarådet. Men ser man på antallet af sa- 
ger, der er under behandling af domstolen i Strasbourg, er der grund til megen bekymring. Her skriver Rusland sig således for 10.569 , men hvis man medtager ældre sager, verserer der for tiden i alt 19.319 russiske sager for domstolen.

Men det har desuden vakt betydelig undren, at Rusland som det eneste land ikke har ratificeret den 14 . tillægsprotokol til den europæiske menneskerettighedskonvention af 1950. Den russiske Duma gav ved en afstemning om dette i december 2006 afkald herpå, selv om den russiske regering løbende sidste år havde lovet at ratificere. Tillægsprotokollen vil muliggøre, at en række klagesager af mindre betydning for klageren vil kunne frasorteres og dermed lette Menneskerettighedsdomstolen, som er ved at segne under byrden af klager, hvoraf omkring 95 pct. dog ikke antages til realitetsbehandling. Sidste år afvistes således 12.000 sager.

\section{Ruslands ansvar i Transdnestr}

Den dom, som ved nytårstide vakte den russiske præsidents vrede, drejer sig om fire mænd af oprindelig moldovisk nationalitet, der havde været underkastet tortur og konventionsstridig frihedsberøvelse enten af Rusland eller Moldova - eller begge stater. De fire, Ilie Ilascu, Alexandru Lesco, Andrei Ivantoc og Tudor Petrov-Popa - i alderen 41 til 52 år - var aktive i Folkefronten for forening af Moldova med Rumænien, men blev i 1992 i byen Tiraspol anholdt af soldater i uniformer fra den tidligere sovjetiske 14. armé.

Anklagen lød på, at de havde forsøgt at bekæmpe 'den lovlige regering i staten Transdnestr' (der er tale om en del af Østmoldova, der i september 1990, eller en måned efter Moldovas uafhængighed af Sovjetunionen, løsrev sig og siden har eksisteret de facto, dvs. uden international anerkendelse). Den daværende sovjet-delstat Moldavien udvidedes i 1940 med hovedparten af den rumænske provins Bessarabien. Ilascu blev af Transdnestrs 'Højesteret' dømt til døden og hans ejendom konfiskeret, mens de andre fik 12-15 års fængsel.

Menneskerettighedsdomstolen, som i dette spegede tilfælde valgte at sende en undersøgelsesdelegation til Moldova, måtte erkende, at Moldova ikke udøvede nogen myndighed i Transdnestr. På den anden side havde Moldova under sine kontakter med Rusland ikke gjort noget som helst for at få de fire mænd løsladt. Selv efter at heftige kampe om Transdnestr var indstillet i 1991, har Rusland økonomisk og militært støttet løsrivelsesrepublikken - og det også efter maj 1998, hvor den europæiske menneskerettighedskonvention trådte i kraft i forhold til Rusland. Det løsrevne område (750.000 indb.) har i realiteten været holdt i live ved hjælp af russiske bajonetter og politisk/økonomisk støtte fra 
Rusland. Moldova blev bundet af menneskerettighedskonventionen fra september 1997.

Ilascu måtte i lang tid leve på 'dødsgangen' i et fængsel, i otte år var han i isolation uden adgang til post eller regelmæssigt at blive vasket, han led under kulden, manglede lægetilsyn og fik for lidt at spise. Alt dette var Rusland ansvarlig for indtil hans løsladelse i 2001. De andre tre er fortsat i fængsel. Ingen af de fire var blevet stillet for en rigtig domstol, hvilket ved deres fængsling indebar en krænkelse af art. 5 om retten til personlig frihed og sikkerhed. Dertil blev de behandlet umenneskeligt og nedværdigende i fængslet. (art. 3). Afgørelse herom med samt den erstatning, der tilkendtes de fire, blev truffet af Strasbourgdomstolen i 2004.

Denne sag er refereret i detaljer for at illustrere, at alle forsøg på fra Strasbourg-systemets side at sætte ret og skel på en objektiv måde alligevel blev underkastet en politisk vurdering og vækker mishag, fordi dommen er gået Rusland imod. Den følger et vigtigt folkeretligt princip, som Menneskerettighedsdomstolen tidligere har fastslået i sager vedrørende Nordcypern, nemlig at et områdes formelle tilhørsforhold undertiden må vige for det reelle. Her nyttede det ikke Tyrkiet, at det henviste til at Republikken Nordcypern udøvede suverænitet - når det tyrkiske militær var den egentlige magthaver. Tyrkiet har siden betalt de godtgørelser for menneskeretskrænkelser, der blev idømt.

\section{Domme bringes ikke ud i livet}

Det er sket tidligere, at enkelte stater, også de gamle vesteuropæiske demokratier, har vaklet i deres forpligtelse over for den europæiske menneskerettighedskonvention, når de er fundet skyldige i en konventionskrænkelse, men til dato har ingen stat dog vægret sig ved at betale den erstatning, der er blevet den pålagt fra Strasbourg - om end det ind imellem har taget lang tid. Det kan ikke undre, at Rusland - ligesom over 20 stater, der tidligere var central- eller østeuropæiske kommunistdiktaturer samt en håndfuld republikker i Centralasien har problemer med at give domstolene den respekt, de fortjener som uafhængig tredje statsmagt. Alligevel finder Menneskerettighedsdomstolen det bittert, at en stor del af de russiske sager drejer sig om manglende eksekvering af domme, afsagt af russiske domstole - et fænomen også borgere i Ukraine trækkes med.

I oktober 2006 udtalte Europarådets Ministerkomité, der bl.a. påser, at Menneskerettighedsdomstolens afgørelser bringes ud i livet, sin bekymring over det voksende antal russiske sager af denne art (20 konkrete blev der her henvist til, men de sidste fem år har bragt hundreder af disse sager tillige med sager om langvarig sagsbehandling og 
unødige lange tilbageholdelser af folk). I den første dom mod Rusland i Strasbourg fik en vis Anatolij Tikhonovitj Burdov i maj 2002 Menneskerettighedsdomstolens ord for, at han virkelig skulle have udbetalt den erstatning, han af retten i byen Shakhty var tilkendt for den skade han havde taget på sit helbred, fordi han tilbage i 1986 havde deltaget $\mathrm{i}$ oprydningsarbejde efter eksplosionen på atomkraftværket i Tjernobyl - et hverv han var udkommanderet til af militæret.

Europarådet har holdt adskillige møder også med deltagelse af Den Europæiske Kommission til effektivisering af Retsvæsenet for at få forbedret såvel Ruslands som andre Europaråds-landes vanskeligheder med at få gennemført domme i praksis. Hertil knytter sig også alt for langstrakte retssager og manglende retssikkerhed i forbindelse med straffesager. Det er velkendt, at fængslerne er overfyldt i mange lande, også i Vesteuropa (fx Storbritannien og Italien) - alligevel virker nogle sager om russiske straffefangers indespærring forfærdende næsten ud over menneskelig forestillingsevne.

Den første russiske sag, Menneskerettighedsdomstolen afgjorde af denne type, vedrørte moskovitten Valerij Kalashnikov, der under afsoningen af en fængselsdom på fem år for bedrageri sammen med 15 andre måtte dele en celle på 17 kvadratmeter. Han pådrog sig flere hudsygdomme og svamp og mistede neglene på hænder og fødder i den uhumske celle, der var fyldt med myrer og kakerlakker. Menneskerettighedsdomstolen karakteriserede i juli 2002 dette som nedværdigende behandling og tilkendte ham en erstatning. Denne ulykkelige sag er desværre blevet påfulgt af en stribe andre for Menneskerettighedsdomstolen.

Det skal dog retfærdigvis tilføjes, at fængselsforholdene generelt er blevet noget forbedret. Ifølge det amerikanske udenrigsministeriums oversigt over menneskeretssituationen i Rusland fra marts 2006 faldt antallet af syge fanger og tilbageholdte 2002-2004 med 27 pct. Tuberkulose er særlig udbredt.

\section{Nedskydning af civile og tortur}

Ruslands forargelse over Menneskerettighedsdomstolens virke er naturligt også cementeret gennem de afgørelser, der er faldet om Tjetjenien. Et kompleks på seks sager, der blev forelagt Menneskerettighedsdomstolen, illustrerer de forfærdende forhold, som civilbefolkningen i den oprørske russisk-kaukasiske delstat er blevet udsat for. Domstolen fandt her Rusland skyldig i alvorlige krænkelser af den europæiske menneskerettighedskonvention. Sagerne, benævnt Khashiyev, Akayeva, Medka Isayeva, Yusupova, Bazayeva og Zara Isayeva efter sagsøgerne, drejede sig om nedskydning af de pågældendes ægtefæller (brud på 
art. 2 i den europæiske menneskerettighedskonvention) og manglende adgang til at gå til domstolene (brud på art.13)

De pågældende blev dræbt under luftbombardementer af Tjetjeniens hovedby Grosnij og ved nedskydninger foretaget af de russiske hærstyrker samt bombardementer af byen Katyr-Yurt i 1999 og 2000. De russiske myndigheder havde godt nok indledt en kriminel efterforskning af hændelserne, men denne var siden hen blevet afbrudt, eftersom angrebene fra russisk side fandtes militært velbegrundede. At den russiske hær i et område spækket med civile fra luften havde nedkastet bomber, hvis skadevoldende radius strakte sig til 1000 meter, var efter domstolens opfattelse i klar strid med de hensyn, et offentligt magtorgan i en demokratisk stat, bør tage.

Det er næppe overdrevent at konkludere, at der i lange perioder har eksisteret et lovløshedens og korruptionens klima i Tjetjenien - selv om regeringen dér har retsforfulgt enkelte militærpersoner med meget blod på hænderne på grund af aktioner mod civile, så er få blevet dømt. I januar 2007 fastslog Menneskerettighedsdomstolen for første gang, at Rusland havde udøvet tortur i Tjetjenien, nemlig mod brødrene Arbi og Adam Chitayev, der bl.a. blev pryglet, udsat for elektro-chok og hensat i iskolde celler. De blev tilbageholdt i tre uger, sigtet for kidnapning og deltagelse i en væbnet oprørsgruppe og blev maltrakteret på mange måder for at 'tilstå'.

Som i en række andre sager, der er gået helt til Strasbourg, var der i denne sket overtrædelse af en stribe andre bestemmelser i menneskeretskonventionen, bl.a. fordi de ikke hurtigt kom for en dommer eller kunne påklage deres anholdelse. Her som i andre tilfælde af menneskeretskrænkelse, blev den russiske stat pålagt at betale en betydelig godtgørelse til ofrene. Ifølge Den Internationale Helsinki-Føderation har de prorussiske myndigheder $\mathrm{i}$ Tjetjenien en række hemmelige arresthuse, hvor fanger torteres. De fleste af dem styres af den hidtidige tjetjenske ministerpræsident Ramzan Kadyrov, der nylig er udnævnt til præsident dér.

\section{Pressefolks farlige liv}

Drabet på den modige russiske journalist Anna Politkovskaja i 2006 har senest rettet fokus mod pressefolks undertiden livsfarlige tilværelse. Beviser på regeringsagenters involvering er få, men indicierne mange. Regeringen - og med den en række større firmaer med tætte forbindelser til regeringen - udsætter løbende en række blade og andre medier for pres, og særlig organer, der har berettet uhildet fra Tjetjenien, har haft vanskeligheder, $\mathrm{fx}$ ved at blive udelukket fra at dække visse begivenheder, ved at blive underkastet krakilske skatteeftersyn, idømt bø- 
der eller pålagt særlige afgifter til at udmarve dem økonomisk.

De 'gammeldags' former for tiltale for at have ærekrænket staten er dog noget på retur efter en afgørelse fra Ruslands Højesteret, som forbyder dette, hvis bladet så går konkurs. Der er betydelig retsusikkerhed, fordi domme undertiden omgøres uden at være appelleret og ikke nødvendigvis i skærpende retning. Ifølge organisationen Glasnost Defense Fund (GDF) bliver journalister ofte fysisk forulempet, og i de sidste 15 år er omkring 45 blevet myrdet. I reglen er disse mord uopklarede.

\section{I gabestokken}

En opbygning af et demokratisk civilsamfund i Rusland er blevet vanskeliggjort efter vedtagelsen af en lov, som påbyder alle udenlandske ngo'er at blive registreret hos myndighederne, officielt for at hindre, at ngo'erne underminerer den nationale sikkerhed, hvortil kommer en særlig antiekstremisme-lov, som ikke alene forbyder ekstremistvirksomhed, men også 'retfærdiggørelse' heraf. Alle russiske ngo'er, der modtager støtte fra udlandet, skal omhyggelig redegøre for anvendelsen heraf.

Det internationale Beskyttelsescenter for ngo'er i Moskva (IPC), der støttes af Den Internationale Juristkommission, blev i 2006 udsat for en seks måneder lang 'revision' af sine regnskaber, gennemført af russiske skattemyndigheder med det resultat, at det blev pålagt en bøde på 1,4 mio. kr.! Et uhyrligt krav, eftersom donationer til et center som IPC ikke skal beskattes. IPC's aktiviteter, der hidtil har omfattet juridisk støtte til ofre for menneskeretskrænkelser, og som har medvirket til at få en bunke sager for Strasbourg-domstolen, er nu droslet ned til det rene ingenting, og en stribe medarbejdere har måttet forlade centret.

Europarådets rådgivende forsamling (bestående af parlamentsmedlemmer fra de 46 medlemslande) har udtrykt stor bekymring over en ny måde, hvorpå russiske myndigheder knægter ytringsfriheden: Ved at beskylde videnskabsmænd og journalister for at have røbet statshemmeligheder og drevet spionage, selv om de har udvekslet informationer, der var offentlig tilgængelige!

Under langstrakte mørklagte retssager uden retsgarantier til de tiltalte er to videnskabsmænd blevet idømt langvarige fængselsstraffe. Den ene, Igor Sutiagin, idømtes således 14 års fængsel efter at være dømt for landsforræderi, selv om han fastholder, at de informationer, han videregav til et konsulentfirma i Storbritannien, var offentlig kendte oplysninger om russiske våbensystemer.

Han deler skæbne med Valentin Danilov, tidligere chef for et termofysisk center, der er idømt 14 års fængsel for at have leveret informationer til Kina - der ifølge hans kol- 
leger blev deklassificeret allerede i 1992. Europarådet har i en resolution opfordret alle medlemslande og her særlig Rusland til ikke at misbruge regler for statens sikkerhed til at mistænkeliggøre videnskabsmænd, journalister og advokater gennem urimelige retssager, hvor vage retsregler er blevet 'bøjet' og udnyttet til at knægte ytringsfriheden.

Selv om retsbeskyttelsen stadig lader en del tilbage at ønske, fx udsættes russiske forsvarsadvokater jævnlig for chikane, så er der sket en del forbedringer og moderniseringer. Således indførtes i 2006 nævningeting, som medførte, at der skete frifindelser i 15 pct. af sagerne mod kun 0,7 pct. af de sager, der kun afgjordes af en dommer. Nye problemer har imidlertid vist sig i form af voldstrusler mod nævninge.

Det 'naturlige' magtmisbrug, som en politimand, officer eller anden offentlig ansat hidtil har udøvet, er på retur. I en nylig sag, der gik til Strasbourg (Kuznetsov-sagen), ville en afdeling af Jehovas Vidner ikke finde sig $\mathrm{i}$, at et lejemål af en sal blev kaldt 'ugyldigt' af en lokal øvrighedsperson, der mødte op ledsaget af to politibetjente. Menneskerettighedsdomstolen pålagde Rusland at betale godtgørelse for denne indgriben i forsamlingsfriheden.

Denne lille sag viser, at menneskerettighederne trods alt er på march også i Rusland.

Henrik Døcker er journalist og forfatter til flere bøger om menneskerettigheder. 